Supporting Information

\title{
Probing Conformational Polymorphism of DNA Assemblies with
}

\section{Nanopores}

\author{
Yingying Sheng ${ }^{1}, \mathrm{Ke} \mathrm{Zhou}^{1}$, Quansheng $\mathrm{Liu}^{2}$, Lei $\mathrm{Liu}^{2}$ and Hai-Chen $\mathrm{Wu}^{1,3^{*}}$
}

${ }^{1}$ Beijing National Laboratory for Molecular Sciences, Key Laboratory of Analytical Chemistry for Living Biosystems, Institute of Chemistry, Chinese Academy of Sciences, Beijing 100190, China

${ }^{2}$ Key Laboratory for Biomedical Effects of Nanomateforrials \& Nanosafety, Multidisciplinary Center, Institute of High Energy Physics, Chinese Academy of Sciences, Beijing 100049, China

${ }^{3}$ University of Chinese Academy of Sciences, Beijing 100049, China

*To whom correspondence should be addressed. Email: haichenwu@iccas.ac.cn 


\section{Supplementary Methods}

\section{Materials and characterization.}

All the DNA samples were purified by HPLC and purchased from Sangon Biotechnology Co., Ltd. (Shanghai). 1,2-Diphytanoyl-sn-glycero-3-phosphochline (DPhPc) was purchased from Avanti Polar Lipids (Alabaster, AL). Melamine, cyanuric acid and other chemicals were purchased from J\&K, Sigma-Aldrich and Alfa Aesar, and used without further purification. All the samples and buffers were prepared in deionized water (Millipore, MA). DNA concentration was measured on ND-2000c Spectrophotometer. Circular dichroism spectra (CD) were collected on a JASCO J-815 spectropolarimeter (Tokyo, Japan). Steady-state fluorescence spectra of the samples in solution were collected in a conventional quartz cell (light path, $10 \mathrm{~mm}$ ) on an F-4500 spectrofluorometer (HITACHI) with $350 \mathrm{~nm}$ light excitation at room temperature. The thermal denaturation experiments were carried out using a Shimadzu model UV-2550 UV-vis spectrophotometer. Wild type $\alpha$ HL-D8H6 proteins were produced as described previously. ${ }^{\mathrm{S} 1}$

\section{Buffer preparation.}

A total of $29.827 \mathrm{~g}$ of $\mathrm{KCl}(99.999 \%$, Sigma-Aldrich), $0.486 \mathrm{~g}$ of $\mathrm{Tris} \cdot \mathrm{HCl}(99.0 \%$, Sigma-Aldrich) and $0.741 \mathrm{~g} \mathrm{MgCl}_{2} \cdot 5 \mathrm{H}_{2} \mathrm{O}(99.0 \%$, Sigma-Aldrich) were dissolved in $370 \mathrm{~mL}$ of deionized water (Millipore, MA). $1 \mathrm{M} \mathrm{NaOH}$ was used to adjust the $\mathrm{pH}$ to 6.5, 6.8, 7.4 and 7.8 and 8.0 respectively. The solution was diluted with deionized water to $400 \mathrm{~mL}$. The final buffer solution consists of $1 \mathrm{M} \mathrm{KCl}, 10 \mathrm{mM}$ Tris and $10 \mathrm{mM} \mathrm{MgCl}_{2}$ at $\mathrm{pH} 6.5,6.8,7.4,7.8$ and 8.0 , respectively. 


\section{Supplementary Figures}

a

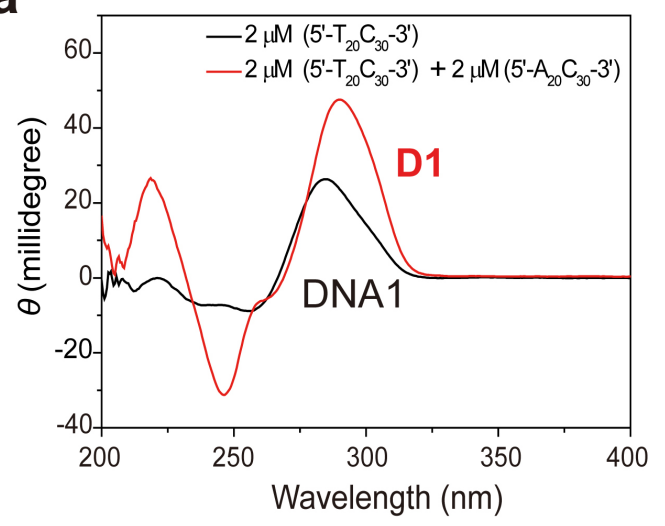

C

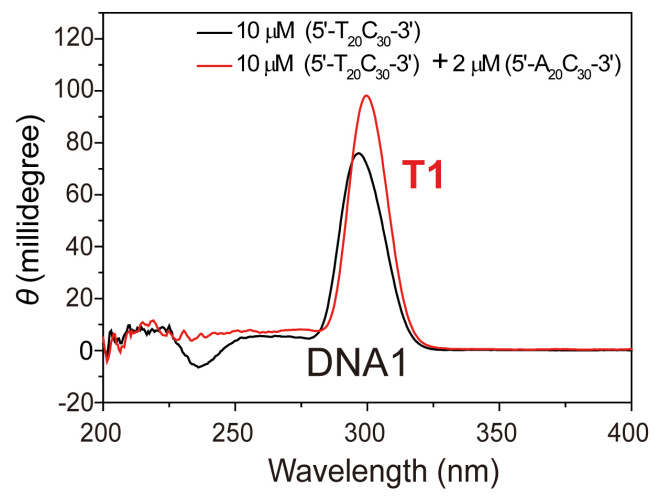

e

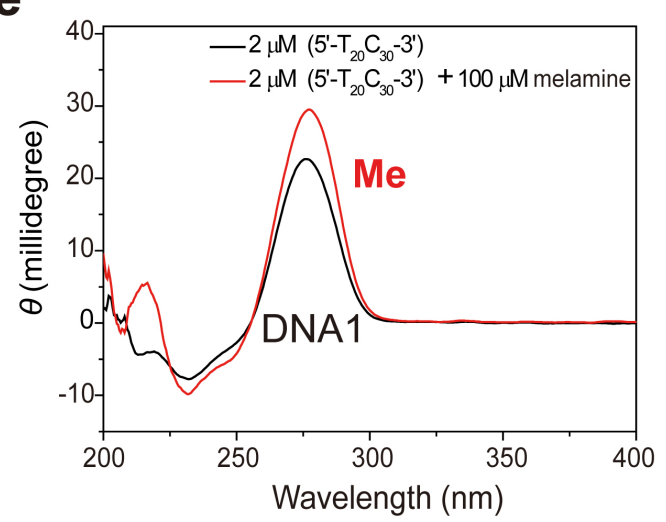

b

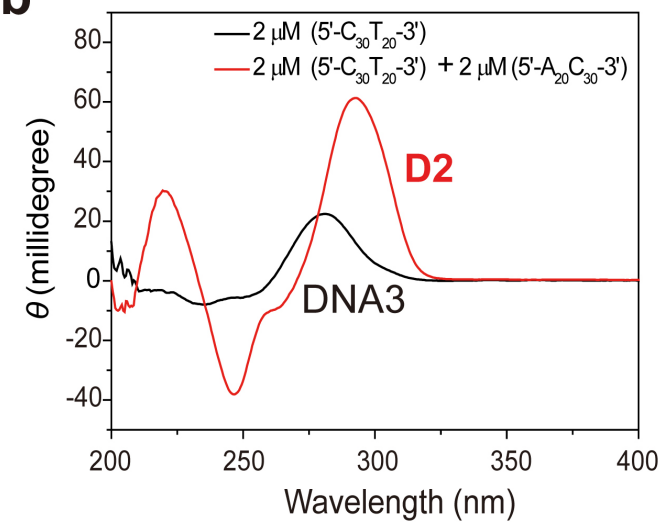

d

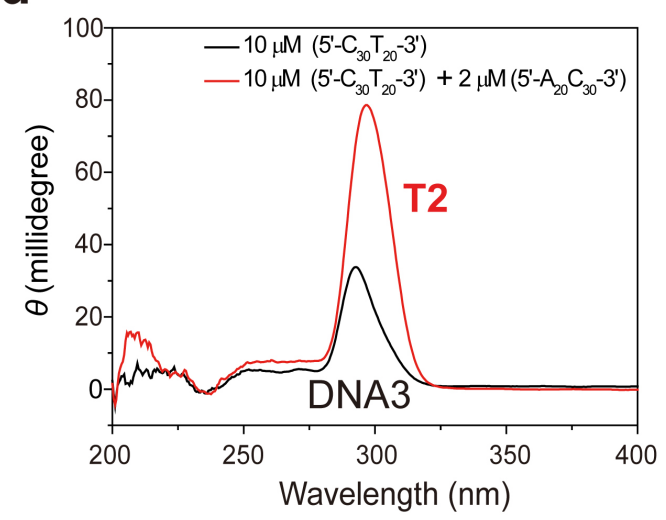

f

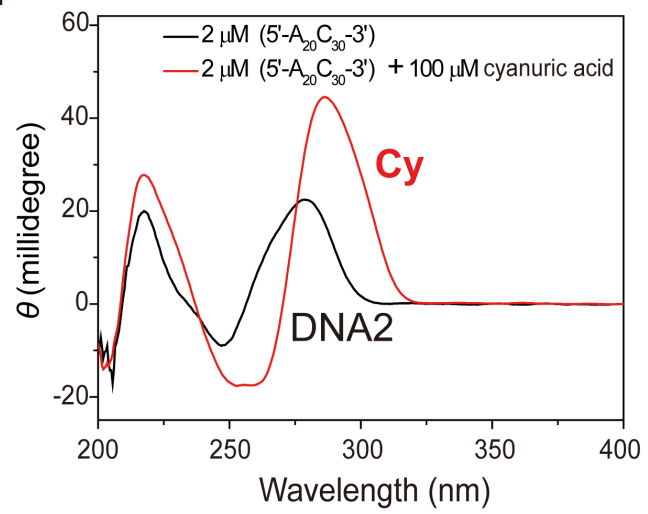

Figure S1. CD spectroscopic characterization of the formation of DNA assemblies. CD spectra of the control DNAs (black) and the DNA assemblies (red) of (a) DNA1 and D1; (b) DNA3 and D2; (c) DNA1 and T1; (d) DNA3 and T2; (e) DNA1 and Me; (f) DNA2 and Cy. The measurements were conducted in $1 \mathrm{~mL}$ buffer of $1 \mathrm{M} \mathrm{KCl}$ buffer, $10 \mathrm{mM}$ Tris. The solution $\mathrm{pH}$ is 7.4 for D1, D2, T1 and T2 measurements; the $\mathrm{pH}$ is 8.0 for Me measurement and 6.8 for $\mathbf{C y}$ measurement. The final concentration of each DNA hybrid is $2.0 \mu \mathrm{M}$; the concentrations of melamine and cyanuric acid are $100.0 \mu \mathrm{M}$. 

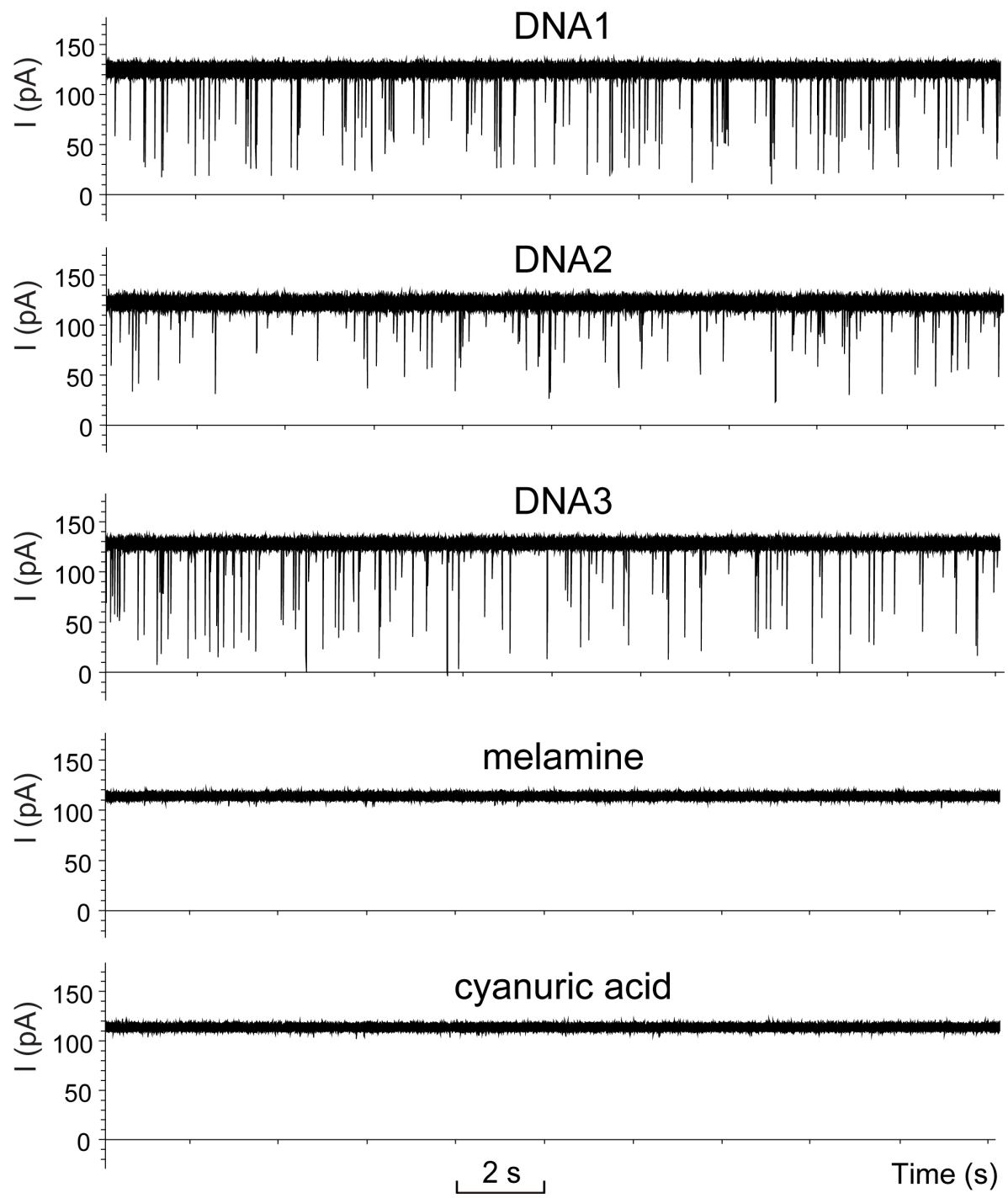

Figure S2. Translocation traces of control experiments. (a) DNA1; (b) DNA2; (c) DNA3; (d) melamine; (e) cyanuric acid. The final concentrations of the DNA samples were $1.0 \mu \mathrm{M}$; the final concentrations of small molecules were $100 \mu \mathrm{M}$. Data were acquired in the buffer of 1 $\mathrm{M} \mathrm{KCl}, 10 \mathrm{mM}$ Tris, $10 \mathrm{mM} \mathrm{MgCl}_{2}$, under the transmembrane potential of $+120 \mathrm{mV}$. 

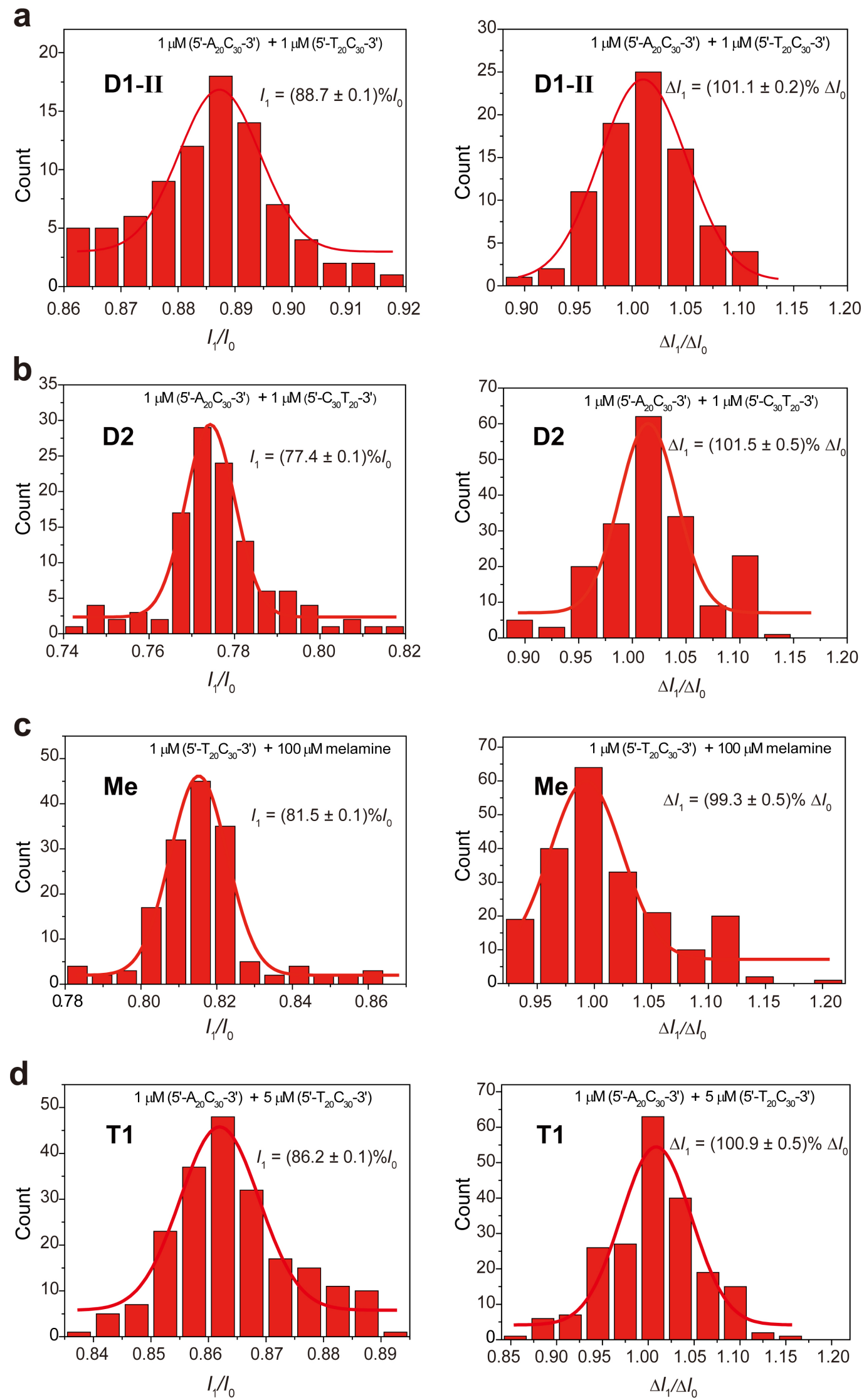

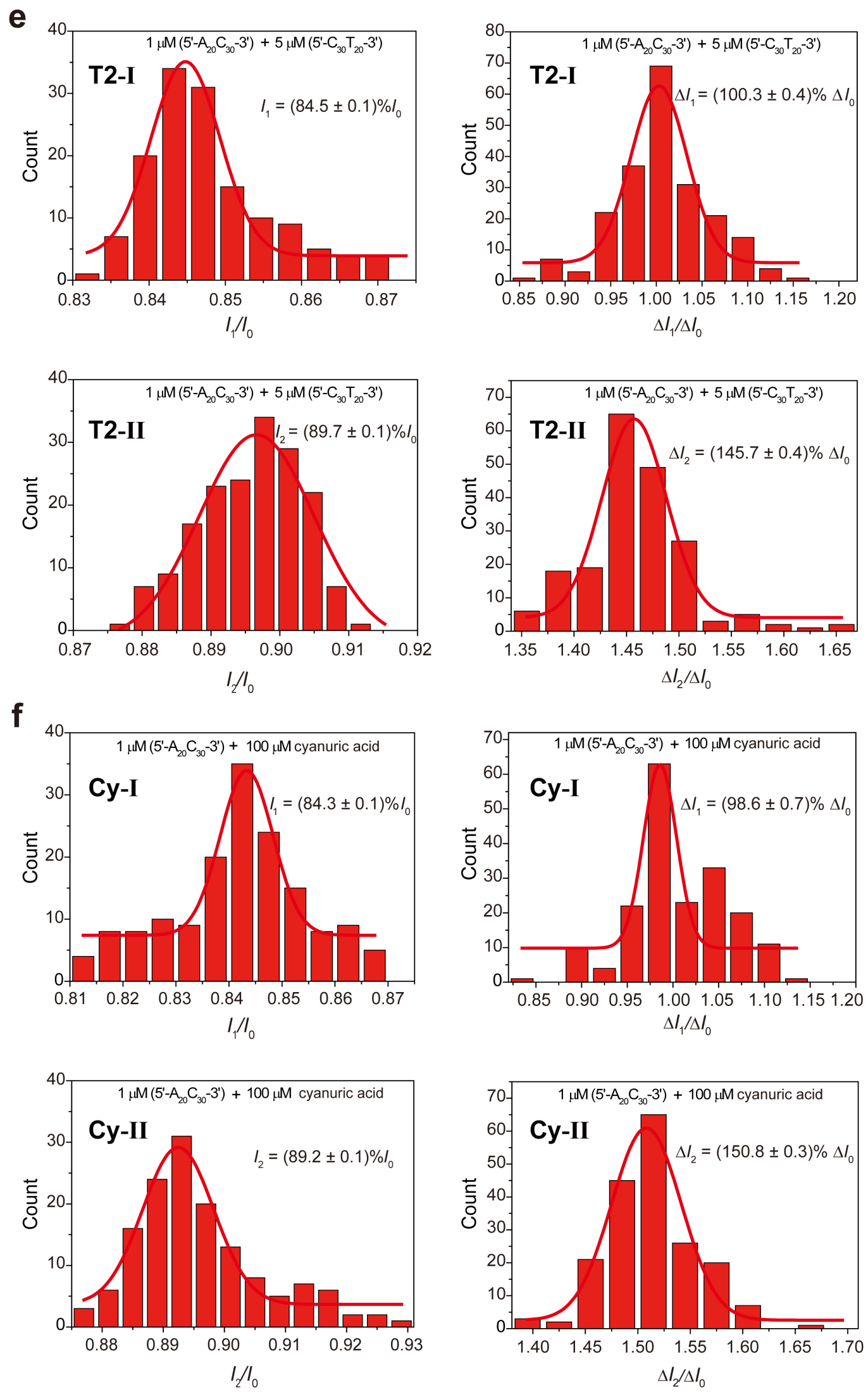

Figure S3. Statistical analyses of the current blockades produced by the DNA assemblies. Left panel: the current blockage of the blockades produced by (a) D1-II; (b) D2; (c) Me; (d) 
T1; (e) T2; (f) Cy. Right panel: the noise ratio of the corresponding blockades. The data of D1, D2, T1 and T2 were acquired in the buffer of $1 \mathrm{M} \mathrm{KCl}, 10 \mathrm{mM}$ Tris, $10 \mathrm{mM} \mathrm{MgCl} 2, \mathrm{pH}$ 7.4, with the transmembrane potential held at $+120 \mathrm{mV}$. The data of Me were acquired at $\mathrm{pH}$ 8.0 under otherwise identical conditions; the data of $\mathbf{C y}$ were acquired at $\mathrm{pH} 6.8$ under otherwise identical conditions. 
(i)

a

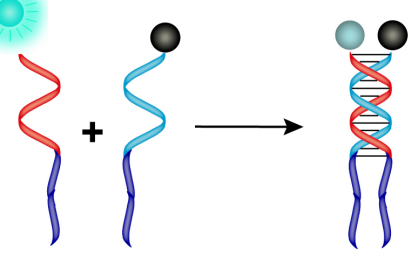

b

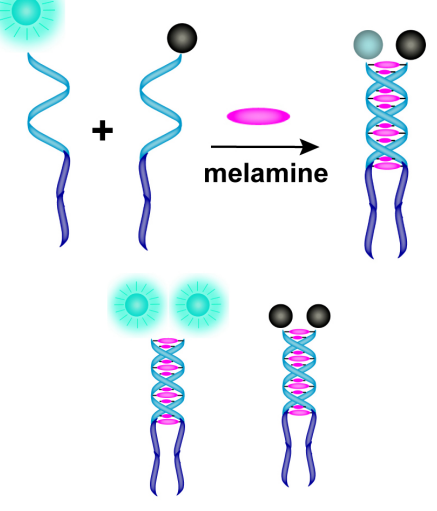

C

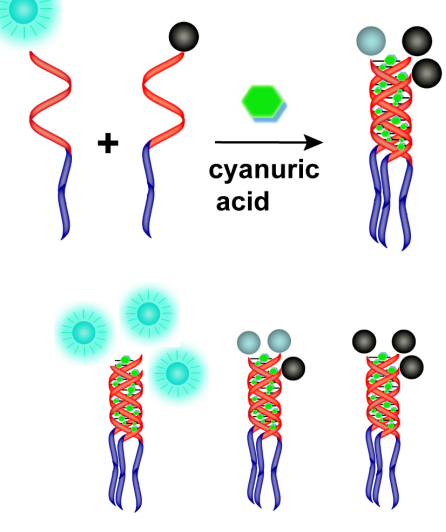

(ii)
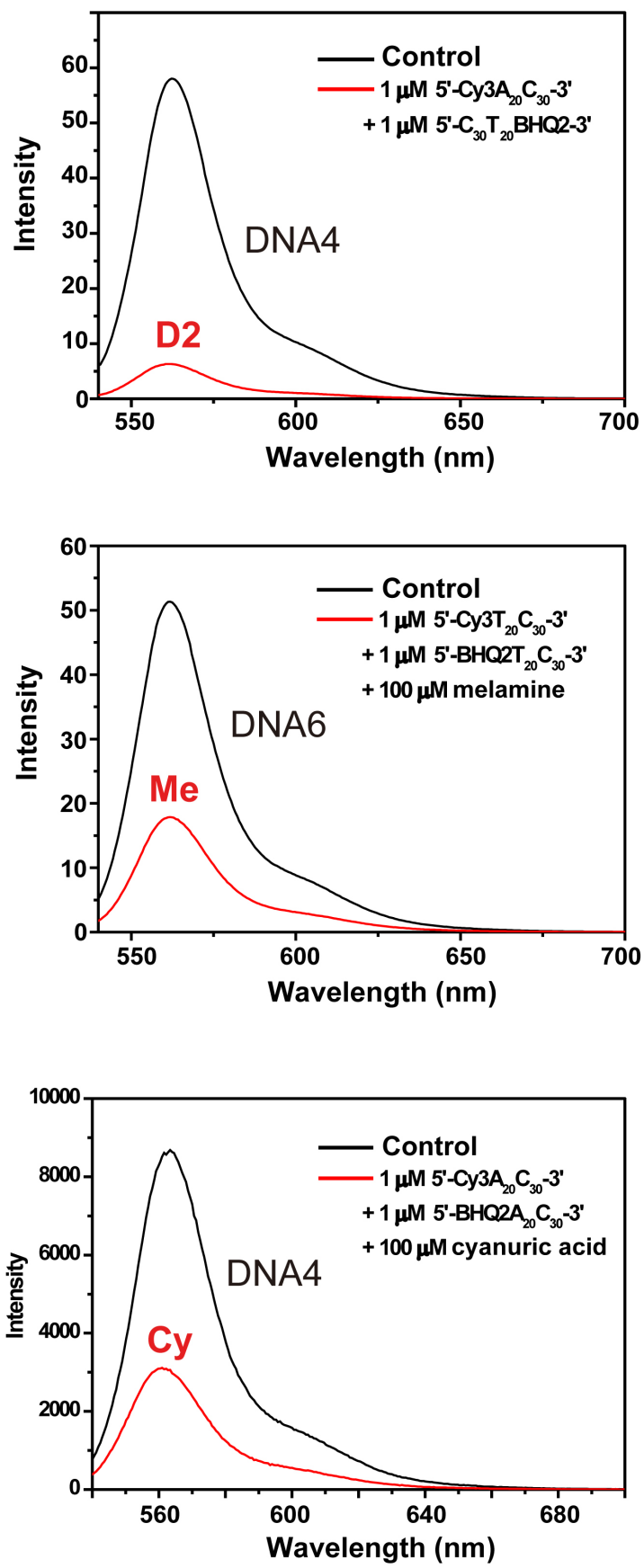

Figure S4. Fluorescence quenching experiments for the confirmation of the orientation of DNA assemblies. (i) The schematic of the fluorescence quenching design for (a) D2; (b) Me; (c) Cy. (ii) The fluorescence spectra of the control DNAs and the DNAassemblies: (a) DNA4 and D2; (b) DNA6 and Me; (c) DNA4 and Cy. The detailed experimental conditions are described in Supplementary Methods. The quenching efficiency of Me or Cy is not as good as that of D2 partly because for Me and $\mathbf{C y}$ there are multiple combinations of the fluorescence-quencher assembly. 

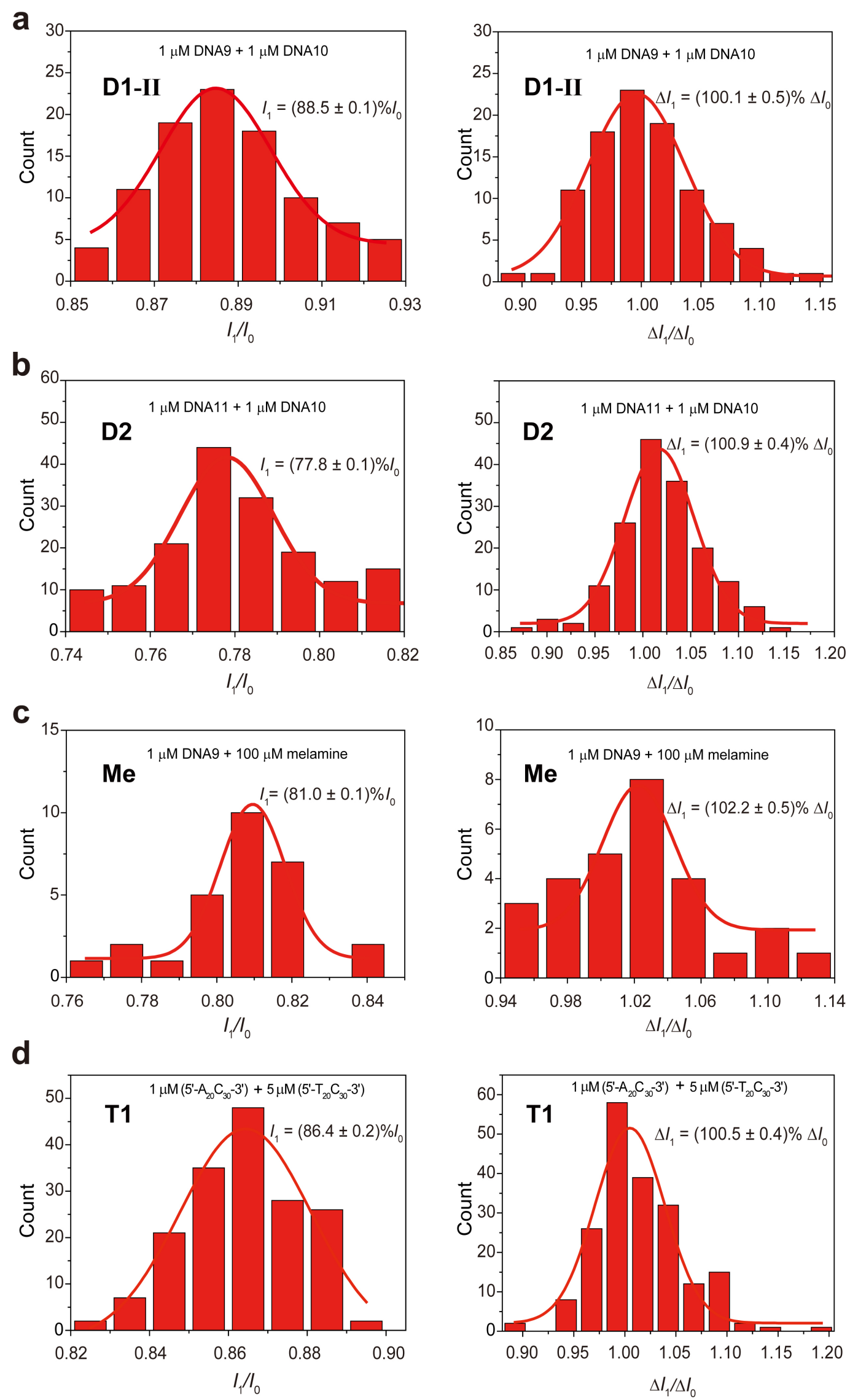

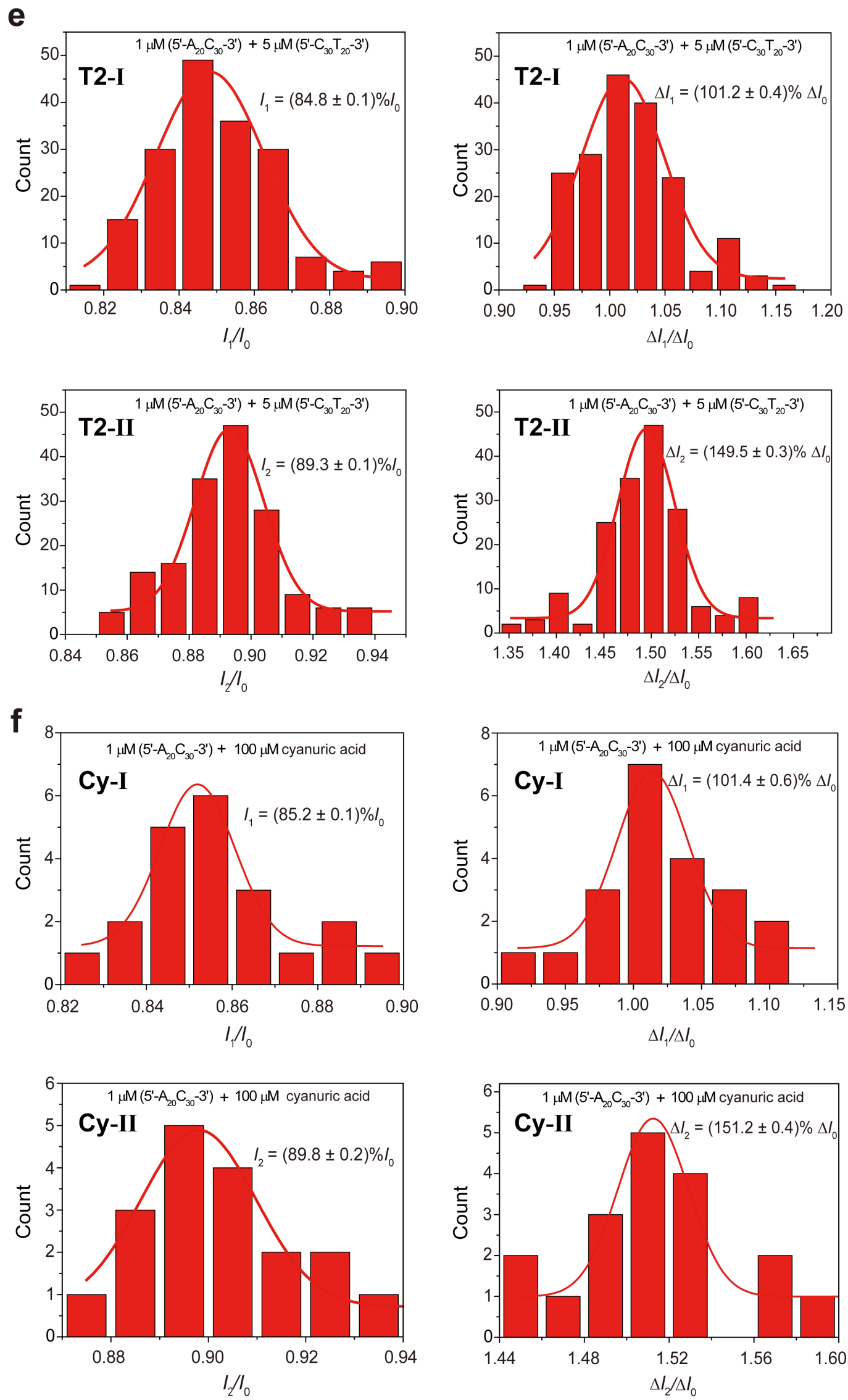

Figure S5. Statistical analyses of the current blockades produced by the DNA assemblies 
under altered $\mathrm{pH}$ conditions. Left panel: the current blockage of the blockades produced by (a) D1-II; (b) D2; (c) Me; (d) T1; (e) T2; (f) Cy. Right panel: the noise ratio of the corresponding blockades. The data of D1, D2, and Me were acquired in the buffer of $1 \mathrm{M}$ $\mathrm{KCl}, 10 \mathrm{mM}$ Tris, $10 \mathrm{mM} \mathrm{MgCl}_{2}, \mathrm{pH} 6.5$, with the transmembrane potential held at $+120 \mathrm{mV}$. The data of T1, T2 and $\mathbf{C y}$ were acquired at pH 7.8 under otherwise identical conditions. 


\section{Supplementary Table}

Table S1 Sequences of DNA probes in this study.

\begin{tabular}{|c|c|c|}
\hline Name & Sequence & Modification \\
\hline DNA1 & $5^{\prime}-(\mathrm{T})_{20}(\mathrm{C})_{30^{-}} 3^{\prime}$ & none \\
\hline DNA2 & $5^{\prime}-(\mathrm{A})_{20}(\mathrm{C})_{30}-3^{\prime}$ & none \\
\hline DNA3 & $5^{\prime}-(\mathrm{C})_{30}(\mathrm{~T})_{20}-3$ ' & none \\
\hline DNA4 & $5^{\prime}-\mathrm{Cy} 3(\mathrm{~A})_{20}(\mathrm{C})_{30}-3^{\prime}$ & $\begin{array}{c}5^{\prime}-\mathrm{Cy} 3 \\
\text { modification }\end{array}$ \\
\hline DNA5 & $5^{\prime}-(\mathrm{C})_{30}(\mathrm{~T})_{20} \mathrm{BHQ} 2-3^{\prime}$ & $\begin{array}{c}\text { 3'-BHQ2 } \\
\text { modification }\end{array}$ \\
\hline DNA6 & $5^{\prime}-\mathrm{Cy} 3(\mathrm{~T})_{20}(\mathrm{C})_{30}{ }^{\prime} 3^{\prime}$ & $\begin{array}{c}5^{9}-\mathrm{Cy} 3 \\
\text { modification }\end{array}$ \\
\hline DNA7 & $5^{\prime}-\mathrm{BHQ} 2(\mathrm{~T})_{20}(\mathrm{C})_{30}-3^{\prime}$ & $\begin{array}{c}\text { 5'-BHQ2 } \\
\text { modification }\end{array}$ \\
\hline DNA8 & $5^{\prime}-\mathrm{BHQ} 2 \mathrm{~A}_{20} \mathrm{C}_{30}-3^{\prime}$ & $\begin{array}{c}\text { 5'-BHQ2 } \\
\text { modification }\end{array}$ \\
\hline DNA9 & $5^{\prime}$-(Т) ${ }_{20}$ CСТАССТАТССТТССАСТСАТТТТССТТАА-3' & none \\
\hline DNA10 & $5^{\prime}$-(A) ${ }_{20}$ ССТАССТАТССТТССАСТСАТТТТССТТАА-3' & none \\
\hline DNA11 & 5 '-ССТАССТАТССТТССАСТСАТТТТССТТАА(Т $)_{20}-3$ ' & none \\
\hline
\end{tabular}

Note: the modified site on DNA is marked in red.

5'-Cy3 modification

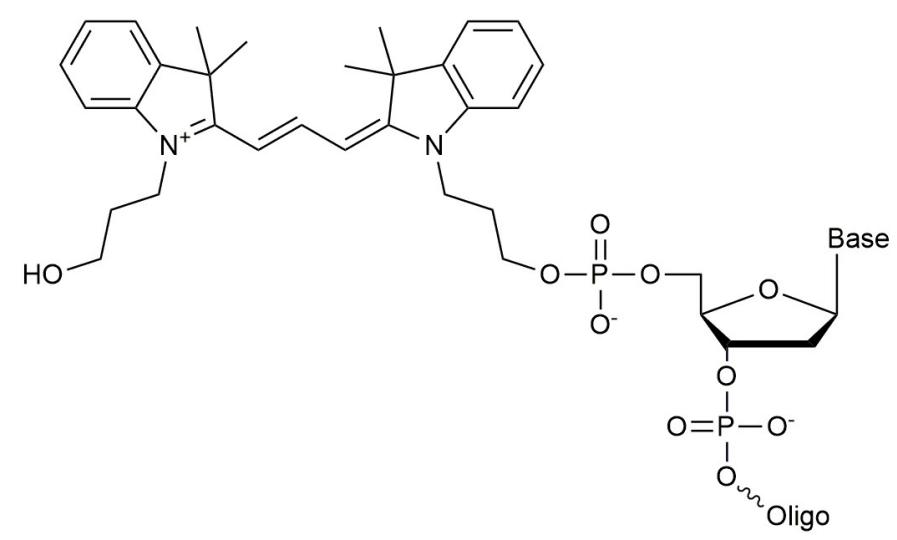


5'-BHQ2 modification

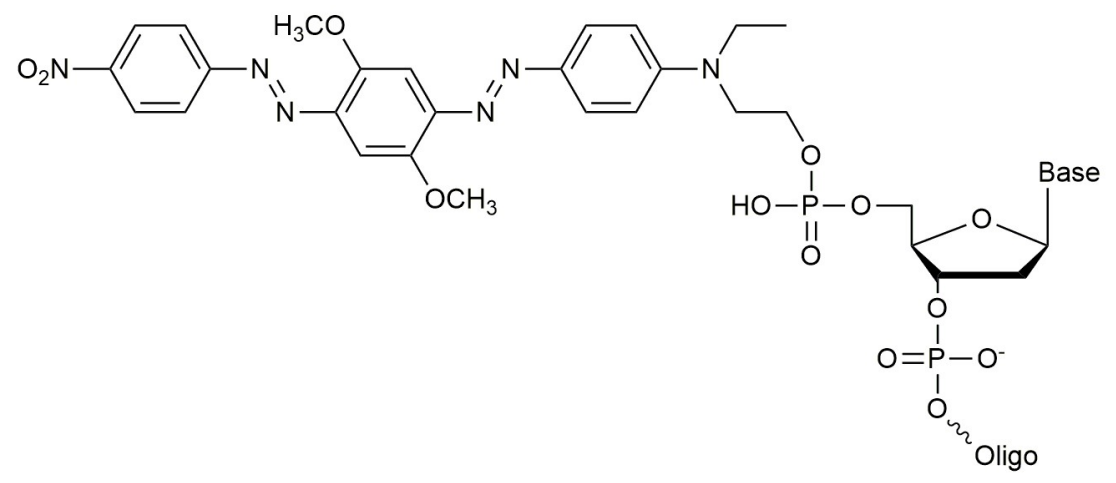

3'-BHQ2 modification

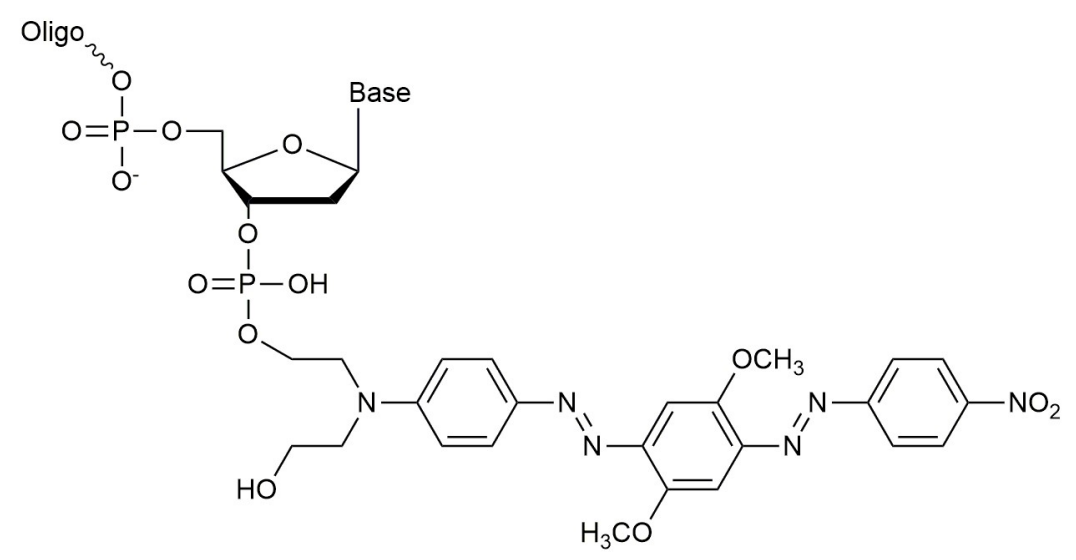




\section{Supplementary References}

(1) Wen, S.; Zeng, T.; Liu, L.; Zhao, K.; Zhao, Y.; Liu, X.; Wu, H.-C., Highly Sensitive and Selective DNA-Based Detection of Mercury(II) with alpha-Hemolysin Nanopore. J. Am. Chem. Soc. 2011, 133 (45), 18312-18317. 